\title{
ANALISIS SEGMENTING, TARGETING DAN POSITIONING UNTUK MERUMUSKAN STRATEGI PEMASARAN GLOBAL PADA UKM KACANG MEDE "BAWANG MAS" SURABAYA
}

\author{
Aisa Diaz Adhe Lusinta ${ }^{1}$ Titin $^{2}$ Luluk Nur Azizah ${ }^{3}$ \\ Prodi Manajemen, Fakultas Ekonomi, Universitas Islam Lamongan \\ $\mathrm{Jl}$. Veteran No.53A Lamongan \\ Telp. ( 0322 ) 324706, Faks. ( 0322 ) 324706
}

Aisadiaz27@gmail.com

\begin{abstract}
Abstrak
Penelitian ini bertujuan untuk mengetahui analisis segmenting, targeting dan positioning untuk dapat merumuskan strategi pemasaran global pada UKM Kacang Mede "Bawang Mas" Surabaya dengan menggunakan populasi berupa data faktor internal dan faktor eksternal pada usaha tersebut yang diambil dari 30 responden. Untuk mengetahui seberapa pengaruhnya penelitian ini menggunakan metode analisis SWOT. Penelitian ini dilakukan dengan cara wawancara, observasi, dokumentasi dan studi kepustakaan pada pimpinan usaha UKM Kacang Mede "Bawang Mas" Surabaya. Hasil dari penelitian ini dianalisis segmenting, targeting dan positioning pada usaha ini lalu dilanjutkan dengan metode analisis SWOTAnalisis strategi segmentasi pasar, target pasar dan posisi produk dengan menggunakan analisis SWOT untuk merumuskan strategi pemasaran Global pada UKM Kacang Mede "Bawang Mas" Surabaya yaitu berasal dari hasil analisis SWOT dengan skor kekuatan (strength) 2.25 ; kelemahan (weakness) 1.29 ; peluang (opportunities) 2.68 ; ancaman (treath) 0.66. Dari hasil perhitungan tersebut dapat dilihat dari selisih skor kekuatan dan kelemahan yang mana nilai skor kekuatan lebih tinggi dari nilai skor kelemahan dengan selisih sebesar 0.96. Sedangkan selisih nilai skor peluang dan ancaman yang mana nilai skor tertinggi adalah peluang dengan selisih sebesar 2.02.Dari hasil tersebut dapat diketahui dalam diagram kuadran analisis SWOT bahwa posisi usaha pada titik kuadran I . Sehingga dapat disimpulkan bahwa UKM Kacang Mede "Bawang Mas" Surabaya telah berada pada jalur yang tepat dengan terus melakukan strategi agresif untuk meningkatkan penjualan dan memperluas pasarnya.
\end{abstract}

Kata Kunci: Segmenting, Targeting, Positioning, Analisis SWOT, Strategi Pemasaran Global, Perluasan Pasar, UKM

\section{PENDAHULUAN}

Perdagangan global saat ini telah dilakukan hampir semua Negara di dunia. Bagi suatu Negara yang melakukan perdaganggan ke luar ngeri jauh lebih menguntungkan apabila dibandingkan dengan Negara lain yang hanya menjalankaan perdangan dalam negeri. Indonesia memiliki banyak komoditi ekspor, salah satunya adalah dalam bidang makanan. Meskipun bukan komoditas ekspor yang utama, namun makanan turut andil dalam meningkatkan 
devisa Negara. Sebelum suatu usaha terjun ke pasar yang dituju untuk mempromosikan produknya, maka ia harus meneliti dulu tentang Segmenting, Targeting dan Positioning. UKM Kacang Mede "Bawang Mas" Surabaya adalah salah satu usaha makanan ringan berupa kacang mede olahan dengan berbagai cita rasa yang dapat menarik pelanggan. Usaha ini telah berhasil menjual produknya hingga ke seluruh Indonesia bahkan telah mendapatkan permintaan dari beberapa Negara.

\section{KAJIAN PUSTAKA}

\section{Pengertian Pemasaran}

Menurut Hasan (2013:4), pemasaran adalah proses mengidentifikasi, menciptakan dan mengkomunikasikan nilai, serta memelihara hubungan yang memuaskan pelanggan untuk memaksimalkan keuntungan perusahaan.

Tujuan pemasaran menurut Hasan (2014:429)mencakup maksimalisasi keuntungan, memaksimalkan pangsa pasar, memaksimalkan penjualan, meningkatkan citra merek, meningkatkan kepuasan pelanggan, menyediakan value dan memelihara stabilitas harga.

Menurut Hasan (2014:436), strategi pemasaran yang baik harus dibangun atas dasar pemahaman bisnis yang kuat, dikombinasikan dengan pemahaman kebutuhan dan keinginan pelanggan, pesaing dan skills, dan core bisnis termasuk dengan para pemasok dan distributor.

"Proses penerapan strategi pemasaran mengharuskan marketer untuk mengidentifikasi kebutuhan dan keinginan pelanggan - pasar sasaran, memuaskan pelanggan (lebih tinggi dari pesaing), dan menjaga pelanggan sebagai sarana untuk keberlanjutan profit”. Hasan(2014:4)

Berdasarkan pengertian di atas dapat disimpulkan bahwa pemasaran adalah proses pencarian atas apa yang diinginkan dan dibutuhkan konsumen, menyediakan barang atau jasa untuk memenuhi keinginan dan kebutuhan tersebut dan mengkomunikasikan nilai barang atau jasa serta penciptaan hubungan dengan pelanggan sehingga dapat menciptakan kepuasan bagi pelanggan dan memberikan laba bagi perusahaan yang bersangkutan.

\section{Pemasaran Global}

Pemasaran Global tidak berarti memasuki setiap Negara di dunia.Keputusan untuk memasuki pasar ke luar negeri tergantung pada sumber daya perusahaan, serta karakteristik peluang dan ancaman yang dihadapi.Pemasaran global adalah pemasaran berkala seluas dunia. Peluang pasar selalu terbuka bagi semua pelaku usaha, tak terkecuali di pasar ekspor. Slideshare (2014). 


\section{UKM ( Usaha Kecil Menengah)}

UMKM adalah usaha produktif yang dimiliki perorangan maupun badan usaha yang telah memenuhi kriteria sebagai usaha mikro.Seperti diatur dalam peraturan perundang-undangan No. 20 tahun 2008, sesuai pengertian UMKM tersebut maka kriteria UMKM dibedakan secara masing-masing meliputi usaha mikro, usaha kecil, dan usaha menengah

\section{Segmentasi Pasar}

Segmentasi pasar merupakan strategi yang sangat penting dalam mengembangkan program pemasaran. Dengan segmentasi pasar,diharapkan usahausaha pemasaran dilakukan dapat mencapai tujuan perusahaan secara efisien dan efektif. Berikut pengertian dari beberapa ahli

Menurut Tjiptono dalam bukunya Pemasaran (2016 :95),pengertian segmentasi pasar adalah sebagai proses mengelompokan pasar keseluruhan yang heterogen menjadi kelompok-kelompok atau segmen- segmen yang memiliki kesamaan dalam hal kebutuhan,keinginan,perilaku dan/atau respon terhadap program pemasarn spesifik".

Segmentasi pasar adalah kegiatan membagi suatu pasar menjadi kelompokkelompok pembeli yang berbeda yang memiliki kebutuhan, karakteristik, atau perilaku yang berbeda yang mungkin membutuhkan produk atau bauran pemasaran yang berbeda. Segmentasi pasar juga dapat diartikan sebagai proses pengidentifikasian dan menganalisis para pembeli di pasar produk, menganalisis perbedaan antara pembeli di pasar.

\section{Target Pasar}

Selama ini terlihat gejala semakin banyak perusahaan memilih pasar sasaran yang akan dituju, keadaan ini dikarenakan mereka menyadari bahwa pada dasarnya mereka tidak dapat melayani seluruh pelanggan dalam pasar tersebut. Terlalu banyaknya pelanggan, sangat berpencar dan tersebar serta bervariatif dalam tuntutan kebutuhan dan keinginannya. Jadi arti dari targeting atau pasar sasaran adalah: Sebuah pasar terdiri dari pelanggan potensial dengan kebutuhan atau keinginan tertentu yang mungkin mau dan mampu untuk ambil bagian dalam jual beli, guna memuaskan kebutuhan atau keinginan tersebut.

$$
\text { Menurut Tjiptono (2016:103), }
$$
pengertian pasar sasaran adalah: "Proses mengevaluasi dan memilih satu atau beberapa segmen pasar yang dinilai paling menarik untuk dilayani dengan program pemasaran spesifik perusahaan”.

Dari definisi di atas dapat disimpulkan bahwa Targeting atau pasar 
sasaran adalah kegiatan dimana perusahaan memilih segmen pasar untuk dimasuki dan kemudian perusahaan dapat menentukan lebih spesifik pasar yang akan dituju.

Targeting adalah proses mengevaluasi setiap daya tarik segmen kemudian memilih satu atau lebih karakteristik untuk dilayani. Targeting adalah persoalan bagaimana memilih, menyeleksi, dan menjangkau pasar. Targeting atau menetapkan target pasar merupakan tahap selanjutnya dari analisis segmentasi. Produk dari targeting adalah target market (pasar sasaran), yaitu satu atau beberapa segmen pasar yang akan menjadi fokus kegiatan-kegiatan pemasaran. Proses targeting mencerminkan kenyataan bahwa perusahaan harus mengidentifikasi pelanggan yang dapat diakses dan dilayani secara efektif dan efisien.

\section{Posisi Pasar}

Hal yang paling penting dalam proses STP ( Segmenting, Targeting, Positioning) adalah mencoba menempatkan produk di benak konsumen dengan ciri-ciri yang untuk yang bisa dibedakan dengan produk lainnya atau disebut positionning. Positioning merupakan cara pemasar menanamkan citra, persepsi dan imajinasi atas produk yang ditawarkan kepada konsumen melalui proses komunikasi.
Positioning tidak sama dengan segmentasi baik difersinasi ataupun konsentrasi. Dengan perkataan lain, positionning bukan menempatkan produk untuk kelompok tertentum tetapi berusaha menanamkan citra produk di benak konsumen pada segmen yang telah dipilih. Positioning berhubungan bagaimana memainkan komunikasi agar dalam benak konsumen trtanam suatu citra tertentu.

MenurutTjiptono mengatakan bahwa(2016:112) :“Adalah cara produk, merek, atau organisasi perusahaan dipersepsikan secara relatif dibandingkan dengan produk, merek atau organisasi pesaing oleh pelanggan saat ini maupun calon pelanggan"

Dengan kata lain positioning adalah suatu tindakan atau langkah-langkah yang dilakukan oleh perusahan dalam upaya penawaran nilai dimana dalam satu segmen tertentu konsumen mengerti dan menghargai apa yang dilakkan suatu perusahan dibandingkan dengan pesaingnya. Jadi positioning bukan menciptakan produk dengan menempatkan pada segmen tertentu, tateapi positioning menempatkan produk di benak konsumen pada segmen tertentu dengan cara komunikasi. Komunikasi yang dibangun oleh pemasar harus menciptakan hubungan yang positif. 


\section{Analisis SWOT}

SWOT adalah metode perencanaan strategis yang digunakan untuk mengevaluasi kekuatan (strengths), kelemahan (weaknesses), peluang (opportunities), dan ancaman (threats) dalam suatu proyek atau suatu spekulasi bisnis. Keempat faktor itulah yang membentuk akronim SWOT (strengths, weaknesses, opportunities, dan threats). SWOT akan lebih baik dibahas dengan menggunakan tabel yang dibuat dalam kertas besar, sehingga dapat dianalisis dengan baik hubungan dari setiap aspek.

Proses ini melibatkan penentuan tujuan yang spesifik dari spekulasi bisnis atau proyek dan mengidentifikasi faktor internal dan eksternal yang mendukung dan yang tidak dalam mencapai tujuan tersebut. Analisis SWOT dapat diterapkan dengan cara menganalisis dan memilah berbagai hal yang mempengaruhi keempat faktornya, kemudian menerapkannya dalam gambar matrik SWOT, di mana aplikasinya adalah bagaimana kekuatan (strengths) mampu mengambil keuntungan (advantage) dari peluang (opportunities) yang ada, bagaimana cara mengatasi kelemahan (weaknesses) yang mencegah keuntungan (advantage) dari peluang (opportunities) yang ada, selanjutnya bagaimana kekuatan (strengths) mampu menghadapi ancaman (threats) yang ada, dan terakhir adalah bagaimana cara mengatasi kelemahan (weaknesses) yang mampu membuat ancaman (threats) menjadi nyata atau menciptakan sebuah ancaman baru.

\section{METODE PENELITIAN}

Jenis Penelitan

Dalam Penelitian ini penulis menggunakan jenis penelitian kualitatif dengan pendekatan deskriptif yaitu sebuah penelitian yang bertujuan membuat pencandraan secara sistematis, factual dan akurat mengenai fakta-fakta dan sifat objek penelitian.

Statistik Deskriptif adalah statistic yang berfungsi untuk mendeskripsikan atau memberikan gambaran terhadap objek yang diteliti melalui data sampel atau populasi sebagaimana adanya, tanpa melakukan analisis dan membuat kesimpulan yang berlaku untuk umum.

Metode penelitian kualitatif adalah metodepenelitian yang berlandaskan filsafat positivisme, digunakan untuk meneliti pada kondisi objek yang alamiah, dimana peneliti adalah sebagai instrument kunci, pengambilan sampel sumber data dilakukan secara purposive dan snowball, teknikpengumpulan data dengan trianggulasi, analisis data bersifat 
induktif/kualitatif dan hasil penelitian lebih menekankan makna dari pada generalisasi. Sugiyono,(2015:19)

\section{Populasi dan Sampel}

\section{Populasi}

Populasi adalah wilayah generalisasi yang terdiri atas objek atau subyek yang mempunyai kualitas dan karakteristik tertentu yang diharapkan oleh bpeneliti untuk dipelajari dan kemudian ditarik kesimpulannya.

Dalam penelitian kualitatif sebenarnya tidak menggunakan istilah populasi tetapi dinamakan oleh situasi sosial yang terdiri dari tempat, perilaku dan aktivitas yang berinteraksi secara strategis. Populasi dalam penelitian ini adalah data dari seluruh kegiatan pada UKM Kacang Mede "Bawang Mas" Surabaya yang di dapat dari wawancara data manajemen usaha, pembeli dan pesaing.

\section{Sampel}

Sampel adalah bagian dari jumlah dari karaktristik yang dimiliki oleh populasi. Sampel dalam penelitian ini adalah sebagian data yang berhubungan dengan permasalahan penelitian.Sampel dalam penelitian ini adalah data yang berhubungan dengan permasalahan penelitian pada faktor internal dan faktor eksternal di UKM Kacang Mede "Bawang Mas" Surabaya yang diambil dari 30 responden.

\section{Teknik Pengambilan Sampel}

Dalam penelitian kualitatif teknik sampel yang sering digunakan adalah purposive sampling dan snowball sampling. Purposive sampling yaitu teknik pengambilan sumber data dengan pertimbangan tertentu. Misalnya orang tersebut dianggap paling tahu tentang apa yang kita harapkan sehingga akan memudahkan peneliti dalam menjelajahi objek/situasi sosial yang akan diteliti. Sedangkan Snowball sampling adalah teknik pengambilan sumber data yang pada awlnya jumlahnya sedikit lama-lama menjadi besar. Dalam pengambilan sampel pertama-tama dipilih satu hingga dua orang, tetapi karena dua orang ini datanya belum lengkap maa peneliti mencari orang yang dipandang lebih tahu dan dapat melengkapi data yang diinginkan. Begitu seterusnya hingga jumlah sampel menjadi banyak . Sugiyono, (2015:217).

\section{Analisis SWOT}

\section{Langkah Penyusunan Tabel IFAS}

a. Masukan faktor-faktor kekuatan dan kelemahan pada Tabel IFAS kolom 1. Susun 5 sampai dengan 10 faktor dari kekuatan, kelemahan

b. Berikan bobot masing-masing faktor strategis pada kolom 2, dengan skala 1,0 (sangat penting) sampai dengan 0,0 (tidak penting). Semua bobot tersebut 
jumlahnya tidak melebihi dari skor total $=1,00$ Faktor-faktor itu diberi bobot didasarkan pengaruh posisi strategis

c. Berikan rating pada kolom 3 untuk masing-masing faktor dengan skala mulai dari 4 (sangat kuat) sampai dengan 1 (lemah), berdasarkan pengaruh faktor tersebut terhadap kodisi kawasan pariwisata bersangkutan. Variabel yang bersifat positif (semua variabel yang masuk kategori kekuatan) diberi nilai dari 1 sampai dengan 4 dengan membandingkan terhadap rata-rata pesaing utama. Sedangkan variabel yang bersifat negatif kebalikannya jika kelemahan besar sekali (dibanding dengan rata-rata pesaing sejenis) nilainya adalah 1 , sedangkan jika nilai kelemahan rendah/di bawah rata-rata pesaing-pesaingnya nilainya 4 .

d. Kalikan bobot dengan nilai (rating) untuk memperoleh faktor pembobotan dalam kolom 4. Hasilnya berupa skor pembobotan untuk masing-masing faktor yang nilainya bervariasi mulai dari 4,0 (menonjol) sampai dengan 1,0 (lemah).

e. Jumlahkan skor pembobotan (pada kolom 4), untuk memperoleh total skor pembobotan bagi kawasan pariwisata yang bersangkutan. Nilai total ini menunjukan bagaimana kawasan pariwisata bereaksi terhadap faktorfaktor strategis internalnya. Skor total ini dapat digunakan untuk membandingkan kawasan pariwisata ini dengan objek wisata lainnya dalam

\section{HASIL DAN PEMBAHASAN}

Analisis SWOT dalam pemasaran produk pada UKM Kacang Mede "Bawang Mas" Surabaya mempunyai hubungan yang signifikan dalam situasi persaingan pemasaran produk .

Mengacu pada tujuan dan sasaran dilakukannya evaluasi atas penerapan analisis SWOT, maka dapat diketahui apa saja yang menjadi kekuatan dan kelemahan UKM Kacang Mede "Bawang Mas" Surabaya dan peluang apa yang mampu mendukung pemasaran produk hingga ancaman yang nantinya akan dihadapi UKM Kacang Mede "Bawang Mas" Surabaya.Berikut ini adalah table rincian mengenai kekuatan, kelemahan, peluang dan ancaman pada UKM Kacang Mede “Bawang Mas” Surabaya:

\section{Tabel 1}

Faktor Internal dan Faktor Eksternal UKM Kacang Mede "Bawang Mas" Surabaya

\begin{tabular}{|l|l|l|}
\hline No. & \multicolumn{1}{|c|}{ Kekuatan } & \multicolumn{1}{c|}{ Kelemahan } \\
\hline 1. & $\begin{array}{l}\text { Memiliki } \\
\text { reputasi } \\
\text { pelayanan }\end{array}$ & $\begin{array}{l}\text { Pengembangan } \\
\text { pemanfaatan } \\
\text { teknologi belum }\end{array}$ \\
\hline
\end{tabular}




\begin{tabular}{|c|c|c|}
\hline No. & Kekuatan & Kelemahan \\
\hline & yang baik & optimal \\
\hline 2. & $\begin{array}{l}\text { Kualitas } \\
\text { produk yang } \\
\text { baik }\end{array}$ & Kurangnya SDM \\
\hline 3. & $\begin{array}{l}\text { Harga produk } \\
\text { bersaing }\end{array}$ & $\begin{array}{l}\text { Kurangnya Modal } \\
\text { untuk memperluas } \\
\text { usaha }\end{array}$ \\
\hline 4. & $\begin{array}{l}\text { Rekruitmen } \\
\text { SDM } \\
\text { berpengalaman }\end{array}$ & $\begin{array}{l}\text { Tata letak produk } \\
\text { kurang efisien }\end{array}$ \\
\hline No. & Peluang & Ancaman \\
\hline 1. & $\begin{array}{l}\text { Tingginya } \\
\text { minat } \\
\text { konsumen }\end{array}$ & $\begin{array}{l}\text { Munculnya } \\
\text { pesaing baru }\end{array}$ \\
\hline 2. & $\begin{array}{l}\text { Memiliki Citra } \\
\text { yang baik di } \\
\text { Surabaya }\end{array}$ & $\begin{array}{l}\text { Konsumen sensitif } \\
\text { dengan harga }\end{array}$ \\
\hline 3. & $\begin{array}{l}\text { Adanya } \\
\text { kepercayaan } \\
\text { konsumen }\end{array}$ & $\begin{array}{l}\text { Munculnya } \\
\text { inovasi produk } \\
\text { kacang mede lain }\end{array}$ \\
\hline 4. & $\begin{array}{l}\text { Mendapatkan } \\
\text { dukungan } \\
\text { pemerintah }\end{array}$ & $\begin{array}{l}\text { Suplier kacang } \\
\text { mede yang tidak } \\
\text { konsisten }\end{array}$ \\
\hline
\end{tabular}

Sumber : Data Diolah

Identifikasi pada faktor internal dan eksternal pada UKM Kacang Mede "Bawang Mas" Surabaya setelah dianalisa, kemudian diberikan bobot dan nilai. Susunan table berikut merupakan hasil analisa yang telah dilakukan pada usaha UKM Kacang Mede "Bawang Mas" Surabaya yang dapat digunakan dalam pelaksanaan strategi pemasaran.

Tabel 2 Faktor Strategi Internal UKM Kacang Mede "Bawang Mas" Surabaya

\begin{tabular}{|l|c|c|c|}
\hline $\begin{array}{c}\text { Faktor-faktor } \\
\text { Strategi } \\
\text { Internal }\end{array}$ & Bobot & Nilai & $\begin{array}{c}\text { Bobot } \\
\mathbf{x} \\
\text { Nilai }\end{array}$ \\
\hline Kekuatan \\
\hline $\begin{array}{l}\text { Memiliki } \\
\text { reputasi } \\
\text { pelayanan } \\
\text { yang baik }\end{array}$ & 0.15 & 4 & 0.6 \\
\hline
\end{tabular}

\begin{tabular}{|c|c|c|c|}
\hline $\begin{array}{c}\text { Faktor-faktor } \\
\text { Strategi } \\
\text { Internal }\end{array}$ & Bobot & Nilai & $\begin{array}{c}\text { Bobot } \\
\mathbf{x} \\
\text { Nilai }\end{array}$ \\
\hline $\begin{array}{l}\text { Kualitas } \\
\text { produk yang } \\
\text { baik }\end{array}$ & 0.15 & 4 & 0.6 \\
\hline $\begin{array}{l}\text { Harga produk } \\
\text { bersaing }\end{array}$ & 0.15 & 3 & 0.45 \\
\hline $\begin{array}{l}\text { Rekruitmen } \\
\text { SDM } \\
\text { berpengalaman }\end{array}$ & 0.15 & 4 & 0.6 \\
\hline Jumlah & & & 2.25 \\
\hline \multicolumn{4}{|l|}{ Kelemahan } \\
\hline $\begin{array}{l}\text { Pengembangan } \\
\text { pemanfaatan } \\
\text { teknologi } \\
\text { belum optimal }\end{array}$ & 0.11 & 3 & 0.33 \\
\hline $\begin{array}{l}\text { Kurangnya } \\
\text { SDM }\end{array}$ & 0.09 & 2 & 0.18 \\
\hline $\begin{array}{l}\text { Kurangnya } \\
\text { Modal untuk } \\
\text { memperluas } \\
\text { usaha }\end{array}$ & 0.10 & 2 & 0.6 \\
\hline $\begin{array}{l}\text { Tata letak } \\
\text { produk kurang } \\
\text { efisien }\end{array}$ & 0.09 & 2 & 0.18 \\
\hline Jumlah & & & 1.29 \\
\hline Total & & & 3,54 \\
\hline
\end{tabular}

Sumber: Data diolah

Total bobot $\mathrm{x}$ nilai pada table 5.9 yang bernilai 3.54 diperoleh dari penjumlahan bobot $\mathrm{x}$ nilai pada faktor kekuatan dan kelemahan, yang digunakan sebagai acuan titik kondisi internal pada UKM Kacang Mede "Bawang Mas" Surabaya . Hasil ini digunakan untuk melihat posisi pasar saat ini

Tabel 3 Faktor Strategi Eksternal UKM Kacang Mede "Bawang Mas"

\begin{tabular}{|l|c|c|c|}
\hline $\begin{array}{c}\text { Faktor- } \\
\text { faktor } \\
\begin{array}{c}\text { Strategi } \\
\text { Eksternal }\end{array}\end{array}$ & Bobot & Nilai & $\begin{array}{c}\text { Bobot } \\
\mathbf{x} \\
\text { Nilai }\end{array}$ \\
\hline Peluang & & \\
\hline $\begin{array}{l}\text { Tingginya } \\
\text { minat } \\
\text { konsumen }\end{array}$ & 0.16 & 4 & 0.64 \\
\hline
\end{tabular}




\begin{tabular}{|l|c|c|c|}
\hline $\begin{array}{c}\text { Faktor- } \\
\text { faktor } \\
\text { Strategi } \\
\text { Eksternal }\end{array}$ & Bobot & Nilai & $\begin{array}{c}\text { Bobot } \\
\mathbf{x} \\
\text { Nilai }\end{array}$ \\
\hline $\begin{array}{l}\text { Memiliki } \\
\text { Citra yang } \\
\text { baik di } \\
\text { Surabaya }\end{array}$ & 0.17 & 4 & 0.68 \\
\hline $\begin{array}{l}\text { Adanya } \\
\text { kepercayaan } \\
\text { konsumen }\end{array}$ & 0.17 & 4 & 0.68 \\
\hline $\begin{array}{l}\text { Mendapatkan } \\
\text { dukungan } \\
\text { pemerintah }\end{array}$ & 0.17 & 4 & 0.68 \\
\hline \multicolumn{1}{|c|}{ Jumlah } & & & \\
\hline Ancaman & & 2 & 0.16 \\
\hline $\begin{array}{l}\text { Munculnya } \\
\text { pesaing baru }\end{array}$ & 0.08 & 2.68 \\
\hline $\begin{array}{l}\text { Konsumen } \\
\text { sensitif } \\
\text { dengan harga }\end{array}$ & 0.09 & 2 & 0.18 \\
\hline $\begin{array}{l}\text { Munculnya } \\
\text { inovasi } \\
\text { produk } \\
\text { kacang mede } \\
\text { lain }\end{array}$ & 0.08 & 2 & 0.16 \\
\hline $\begin{array}{l}\text { Suplier } \\
\text { kacang mede } \\
\text { yang tidak } \\
\text { konsisten }\end{array}$ & 0.08 & 2 & 0.16 \\
\hline \multicolumn{1}{|c|}{ Jumlah } & & $\mathbf{3 . 3 4}$ \\
\hline Total & & & \\
\hline Sumbr Data & & & \\
\hline
\end{tabular}

Sumber: Data diolah

Total bobot $\mathrm{x}$ nilai pada table 5.10 yang bernilai 3.34 diperoleh dari penjumlahan bobot $\mathrm{x}$ nilai pada faktor peluang dan ancaman, yang digunakan sebagai acuan titik kondisi eksternal pada UKM Kacang Mede "Bawang Mas" Surabaya . Hasil ini digunakan untuk melihat posisi pasar saat ini.

Penilaian terhadap faktor internal dan eksternal yang dimiliki UKM Kacang Mede "Bawang Mas" Surabaya dapat diperoleh total skor yang merupakan jumlah hasil perkalian bobot dengan nilai. UKM Kacang Mede "Bawang Mas" Surabaya memperoleh total skor 3.54 untuk faktor strategi internal, sedangkan pada faktor strategis eksternal menghasilkan total skor 3.34 .

Berdasarkan tabel IFAS dan EFAS di atas dapat diketahui selisih nilai Strength dan Weakness sebesar (+) 0.96 sedangkan Opportunities dan Threat sebesar (+) 2.02. Dari hasil identifikasi tersebut dapat digambarkan dalam diagram SWOT berikut

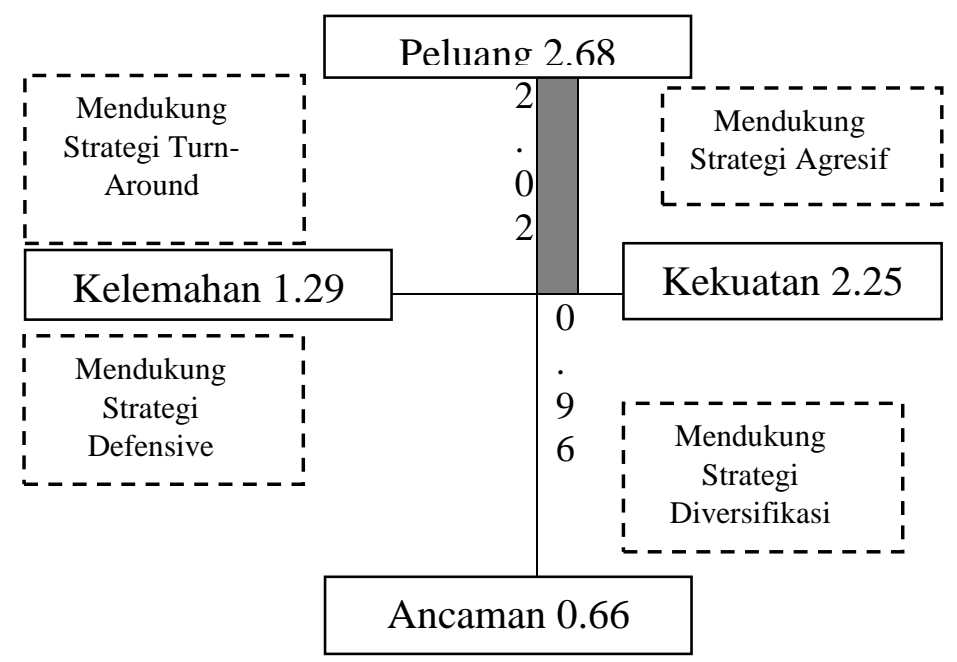

\section{Gambar 1 Diagram Kuadran SWOT UKM Kacang Mede "Bawang Mas" Surabaya"}

Dari hasil diatas menunjukan bahwa UKM Kacang Mede "Bawang Mas" Surabaya masuk pada tipe kuadran I (Positif,Positif). Posisi ini menandakan usaha ini dalam kondisi kuat dan berpeluang, sehingga sangat dimungkinkan untuk terus melakukan ekspansi, 
memperbesar dan meraih kemajuan secara maksimal.

\section{Perumusan Strategi Alternatif}

Untuk menyusun formulasi alternative strategi UKM Kacang Mede "Bawang Mas" Surabaya dengan menggunakan analisis SWOT, alternative-alternatif strategi disusun berdasarkan interaksi atas faktor internal dan eksternal perusahaan . Beberapa alternative strategi usaha dapat dilihat dari table berikut:

Tabel 4, Matrik SWOT

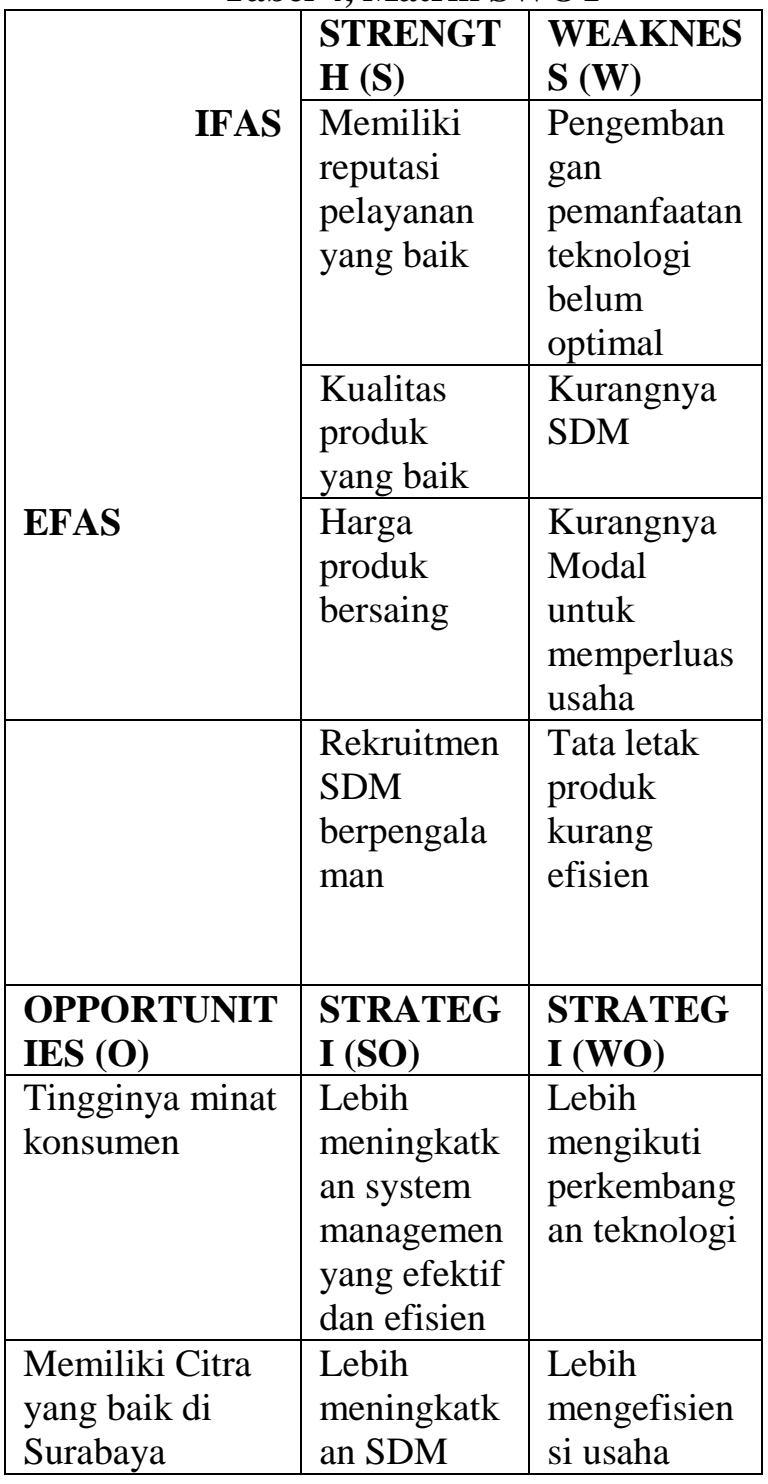

\begin{tabular}{|l|l|l|}
\hline & $\begin{array}{l}\text { agar tetap } \\
\text { dipercaya } \\
\text { konsumen }\end{array}$ & \\
\hline $\begin{array}{l}\text { Adanya } \\
\text { kepercayaan } \\
\text { konsumen }\end{array}$ & $\begin{array}{l}\text { Menentuka } \\
\text { n segmen } \\
\text { pasar, target } \\
\text { pasar dan } \\
\text { posisi } \\
\text { produk }\end{array}$ & \\
\hline $\begin{array}{l}\text { Mendapatkan } \\
\text { dukungan } \\
\text { pemerintah }\end{array}$ & $\begin{array}{l}\text { Memberani } \\
\text { kan diri } \\
\text { memasuki } \\
\text { pasar global }\end{array}$ & \\
\hline THREATS (T) & $\begin{array}{l}\text { STRATEG } \\
\text { I (ST) }\end{array}$ & $\begin{array}{l}\text { STRATEG } \\
\text { I (WT) }\end{array}$ \\
\hline $\begin{array}{l}\text { Munculnya } \\
\text { pesaing baru }\end{array}$ & $\begin{array}{l}\text { Meningkatk } \\
\text { an kinerja } \\
\text { SDM }\end{array}$ & $\begin{array}{l}\text { Memperban } \\
\text { yak } \\
\text { mitrakerja }\end{array}$ \\
\hline $\begin{array}{l}\text { Konsumen } \\
\text { sensitif dengan } \\
\text { harga }\end{array}$ & $\begin{array}{l}\text { Menetapkan } \\
\text { strategi } \\
\text { Harga }\end{array}$ & $\begin{array}{l}\text { Memperluas } \\
\text { usaha dan } \\
\text { membuka } \\
\text { usaha baru }\end{array}$ \\
\hline $\begin{array}{l}\text { Munculnya } \\
\text { inovasi produk } \\
\text { kacang mede } \\
\text { lain }\end{array}$ & $\begin{array}{l}\text { Selektif } \\
\text { dalam } \\
\text { strategi } \\
\text { pemasaran }\end{array}$ & \\
\hline $\begin{array}{l}\text { Suplier kacang } \\
\text { mede yang tidak } \\
\text { konsisten }\end{array}$ & $\begin{array}{l}\text { Sum : } \\
\text { parang }\end{array}$ & \\
\hline
\end{tabular}

Sumber : Data diolah

\section{Pemilihan Strategi Terbaik \\ Tabel 5}

Matrik Pemilihan Strategi Terbaik

\begin{tabular}{|c|c|c|}
\hline IFAS & $\begin{array}{l}\text { STRENGTH } \\
\text { (KEKUATA } \\
\text { N) }\end{array}$ & $\begin{array}{c}\text { WEAKNE } \\
\text { SS } \\
\text { (KELEMA } \\
\text { HAN) }\end{array}$ \\
\hline & SO & WO \\
\hline $\begin{array}{l}\text { OPPORTUN } \\
\text { ITIES } \\
\text { (PELUANG) }\end{array}$ & $\begin{array}{c}\text { (AGRESIF) } \\
2.25+2.68= \\
4.93\end{array}$ & $\begin{array}{c}\text { (TURN- } \\
\text { AROUND) } \\
1.29+2,68 \\
=3.97\end{array}$ \\
\hline & ST & WT \\
\hline $\begin{array}{c}\text { THREAT } \\
\text { (ANCAMAN } \\
\text { ) }\end{array}$ & $\begin{array}{c}\text { (DIVERSIFI } \\
\text { KASI) } \\
2.25+0.66= \\
2.91\end{array}$ & $\begin{array}{c}\text { (DEFERSI } \\
\text { F) } \\
1.29+0.66 \\
=1.92\end{array}$ \\
\hline
\end{tabular}

Dari hasil analisis diatas dengan menggunakan analisi SWOT dari beberapa 
faktor internal dan faktor eksternal untuk strategi pemasaran global bagi UKM Kacang Mede "Bawang Mas" Surabaya untuk mengatasipersaingan dan memperluas pasar menggunakan strategi SO.

1. Lebih meningkatkan sistem manajemen yang efektif dan efisien

Dalam mencapai tujuan usaha untuk meningkatkan penjualan UKM Kacang Mede "Bawang Mas" harus lebih efektif meningkatkan manajemen pemasaran dan SDM dengan cara menjalin hubungan baik dengan konsumen dan jugamitra usaha lain agar memudahkanpemasaran pada usaha supaya pemasaran dapat efektif dan efisien sehingga peningkatan penjualan dapat tercapai.

2. Lebih meningkatkan SDM agar tetap dipercaya konsumen

Untuk lebih mempererat hubungan dengan konsumen, maka SDM yang dimiliki harus lebih meningkatkan pelayanannya supaya konsumen dapat percaya dan citra usaha tetap ada pada konsumen dan tentunya konsumen dapat bertambah agar penjualan meningkat.

3. Menentukan strategi segmen pasar, target pasar dan posisi produk

Dalam hal ini UKM Kacang Mede "Bawang Mas" harus menentukan strategi perusahaan berdasarkan segmenting, targeting dan positioning adalah perusahaan dapat mengembangkan inovasi pada produk, membuat klasifikasi pasar, menargetkan pasar yang potensial kemudian menempatkan perusahaan pada posisi tertentu di mata pasar yang ditargetkan.

4. Memberanikan diri memasuki pasar Global UKM Kacang Mede "Bawang Mas" Surabaya harus dapat memberanikan diri untuk memasuki pasar global dengan memanfaatkan dukungan pemerintah terhadap UKM di Indonesia serta meningkatkan promosi produk dan relasi agar usaha dapat dikenal di pasar Global.

\section{KESIMPULAN}

Berdasarkan dari hasil pembahasan analisa atas masalah yang telah dikemukakan sebelumnya, maka diperoleh kesimpulan sebagai berikut :

Penerapan strategi segmentasi pasar, target pasar dan posisi produk dengan menggunakan pendekatan analisis SWOT untuk merumuskan pemasaran Global pada UKM Kacang Mede "Bawang Mas" Surabaya yaitu berasal dari hasil analisis SWOT dengan skor kekuatan (strength) 2.25 : kelemahan (weakness) 1.29 : peluang (opportunities) 2.68 : ancaman (treath) 0.66. Dari hasil perhitungan tersebut dapat dilihat dari selisih skor kekuatan dan 
kelemahan yang dimana nilai skor kekuatan lebih tinggi dari nilai skor kelemahan dengan selisih sebesar 0.96. Sedangkan selisih nilai skor peluang dan ancaman yang mana nilai skor tertinggi adalah peluang dengan selisih sebesar 2.02. Sehingga dapat disimpulkan bahwa UKM Kacang Mede "Bawang Mas" Surabaya telah berada pada jalur yang tepat dengan terus melakukan strategi agresif untuk meningkatkan penjualan dan memperluas pasarnya.

Kebijakan analisis strategi segmenting, targeting dan positioning produk untuk merumuskan strategi pemasaran global pada UKM Kacang Mede "Bawang Mas" Surabaya yaitu menggunakan perumusan strategi efektif yang akhirnya diperoleh strategi agresif SO yaitu strategi kekuatan yang memanfaatkan peluang yang dimiliki usaha yaitu :

a. Lebih meningkatkan sistem manajemen yang efektif dan efisien

Dalam mencapai tujuan usaha untuk meningkatkan penjualan UKM Kacang Mede "Bawang Mas" harus lebih efektif meningkatkan manajemen pemasaran dan SDM dengan cara menjalin hubungan baik dengan konsumen dan jugamitra usaha lain agar memudahkanpemasaran pada usaha supaya pemasaran dapat efektif dan efisien sehingga peningkatan penjualan dapat tercapai.

b. Lebih meningkatkan SDM gar tetap dipercaya konsumen

Untuk lebih mempererat hubungan dengan konsumen, maka SDM yang dimiliki harus lebih meningkatkan pelayanannya supaya konsumen dapat percaya dan citra usaha tetap ada pada konsumen dan tentunya konsumen dapat bertambah agar penjualan meningkat.

c. Menentukan segmentasi pasar, target pasar dan posisi produk

Strategi perusahaan berdasarkan segmenting, targeting dan positioning adalah perusahaan dapat mengembangkan inovasi pada produk, membuat klasifikasi pasar, menargetkan pasar yang potensial kemudian menempatkan perusahaan pada posisi tertentu di mata pasar yang ditargetkan.

d. Memberanikan diri memasuki pasar Global.

UKM Kacang Mede "Bawang
Mas" Surabaya harus dapat
memberanikan diri untuk memasuki
pasar global dengan memanfaatkan
dukungan pemerintah terhadap UKM
di Indonesia serta meningkatkan


promosi produk dan relasi agar usaha dapat dikenal di pasar Global.

\section{DAFTAR PUSTAKA}

Aaker , David A. 2013 . Manajemen Pemasaran Strategi . Edisi Ke-8. Selemba Empat. Jakarta.

Astina, Sylvia Tri, Sunarti, dan M. Kholid Mawardi. $2016 . \quad$ Analisis Segmentation, Targeting, dan Positioning dalam Rangka Meningkatkan Daya Saing Melalui Strategi Pemasaran di took Pia Cap Mangkok Semeru.

Fidiyati, Nur, Jamaludin Malik, dan Leonardo Budi. 2017. Strategi Pemasaran Industri Mabel dalam Menembus Pasar Global Melalui Analisis SWOT pada CV Mandiri Abadi Jepara.

Kasali, Rhenald. "Membidik Pasar Indonesia :Segmentasi, Targeting dan Positioning" . Jakarta: PT Gramedia Pustaka Utama 1998

Limakrisna, Nandan . 2012. Manajemen Pemasaran : Teori dan aplikasi dalam bisnis. Edisi Pertama. Jakarta : Mitra Wacana Media.

Mahfud, Judin.2014. “Analisis SWOT untuk menentukan strategi kompetitif pada UD Damai 4 Gresik".
Mizrahi, Olga . 2015. "Sell local, Think Global". Solo. Penerbit : Tiga Serangkai

Nugroho, Agung Setyo. 2016. Penerapan Strategi Segmentasi Pasar dan Positioning Produk dengan Pendekatan Analisis SWOT untuk Meningkatkan Penjualan pada UD Panji Desa Sidomulyo Kec. Deket Kab. Lamongan.

Pranoto, Eka Dharma. 2015. Business Global Survival Kit. Edisi I. Yogyakarta.: CV Andi Offset.

Ramadhan, Ahmad Dan Sofiyah, 2013. Analisis SWOT Sebagai Landasan Dalam Menentukan Strategi Pemasaran. USU.

Rangkuti, Freddy. 2004. Analisis SWOT, Teknik Membedah Kasus Bisnis. Penerbit: PT Gramedia Pustaka Utama, Jakarta.

Sari, Marta Widian. 2015. Analisis Segmenting, Targeting dan Positioning untuk Merumuskan Strategi Pemasaran Regional pada UMKM Christine Hakim di Padang. Slideshare, 2014. "Manajemen Pemasaran Global Internasional". https://www.slideshare.net . di akses pada 10 Januari 2019.

Sugiyono. 2014. Metode Penelitian Bisnis :Pendekatan kuantitatif, kualitatif 
dan $R \& D$. Cetakan ke-18. Bandung:

CV Alfabeta

Sugiyono. 2017. Metode Penelitian

Kombinasi (Mixed Methods).

Bandung: Alfabeta. Hal. 99-102.

Thidi, 2017. "Implementasi Strategi Bisnis

Perencanaan Pemasaran Produk Dan

Jasa" https://www.thidiweb.com, di akses pada 15 Juni 2019.

Tjiptono, Fandy. 2016. Pemasaran : Esensi dan Aplikasi. Yogyakarta: CV ANDI OFFSET

UU No. 20 Tahun 2008 tentang koperasi dan UMKM . Diakses pada tanggal 22 oktober 2018.

Wajidi, M. Farid. 2013. "Perspektif Pemasaran Global Dalam Bisnis Internasional". Prodi Manajemen Fakultas Ekonomika dan Bisnis, Universitas Muhammadiyah Surakarta.

Wikipedia, 2019. "Usaha Kecil dan

Menengah".

https://id.m.wikipedia.org/wiki/Usaha _Kecil_dan_Menengah.di akses pada 15 Januari 2019 